\title{
UM CORPO HERÉTICO NO RAP: UMA TEOPOÉTICA ERÓTICA EM ALICE GUÉL*
}

\author{
Bruno Carvalho Rocha**
}

\section{RESUMO}

Este artigo analisa a obra da rapper Alice Guél na perspectiva dos estudos em teopoética. Seu rap é atravessado por questões de gênero, raça e classe. Sua poética se desenvolve entre os conflitos sociais de um corpo transgênero que reivindica uma experiência religiosa singular. Enquanto mulher trans, o corpo tem lugar de destaque: ele é suporte para novos sentidos teológicos, sendo também um lugar hermenêutico para o estabelecimento de uma mística erótico-herética política. Além da contextualização biográfica, localizaremos a obra de Alice Guél dentro do rap nacional, principalmente, a partir das recentes discussões sobre identidade de gênero nesta cultura. Para concluir, analisaremos dois dos seus álbuns, refletindo sobre o lugar do corpo transgênero enquanto lugar teopoético, produtor de múltiplas experiências.

Palavras-chave: Alice Guél; rap; teopoética; erotismo; corpo.

\section{A HERETIC BODY IN RAP MUSIC: AN EROTIC THEOPOETICS IN ALICE GUÉL}

\section{ABSTRACT}

This article analyzes the work of the rapper Alice Guél from the perspective of studies in theopoetics. Her rap is crossed by issues of gender, race and social class. Her poetic develops between the social conflicts of a transgender body that claims a unique religious experience. As a trans woman, the body has a prominent place: it is a support for new theological senses, and also a hermeneutical place

* O presente artigo é resultado da comunicação apresentada no X Congresso Internacional em Ciências da Religião, Sessão Temática 19, Gênero e Religião, em 22/10/2020.

** Teólogo, Mestrando em Ciências da Religião na Universidade Metodista de São Paulo (UMESP). Bolsista CNPq. Membro do Grupo de Pesquisa LITERE - Literatura, teorias da linguagem e religião. 
for the establishment of an erotic-heretical political mystique. In addition to the biographical contextualization, we will locate Alice Guél's work within national rap, mainly based on the recent discussions on gender identity in the culture. To conclude, it will be analyzed two of her albums, reflecting on the place of the transgender body as theopoetic, producer of multiple experiences.

Keywords: Alice Guél; rap; theopoetics; eroticism; body.

\section{UN CUERPO HEREJE EN EL RAP: UNA TEOPOÉTICA ERÓTICA EN ALICE GUÉL}

\section{RESUMEN}

Este artículo analiza la obra de la rapera Alice Guél desde la perspectiva de los estudios en teopoética. Su rap está atravesado por cuestiones de género, raza y clase. Su poética se desarrolla entre los conflictos sociales de un cuerpo transgénero que reivindica una experiencia religiosa única. Como mujer trans, el cuerpo tiene un lugar destacado: es un soporte de nuevos sentidos teológicos, y también es un lugar hermenéutico para el establecimiento de una mística política erótico-herética. Además de la contextualización biográfica, ubicaremos el trabajo de Alice Guél dentro del rap nacional, principalmente a partir de las recientes discusiones sobre la identidad de género en esta cultura. Para finalizar, analizaremos dos de sus álbumes, reflexionando sobre el lugar del cuerpo transgénero como lugar teopoético, productor de múltiples experiencias.

Palabras clave: Alice Guél; rap; teopoética; erotismo; cuerpo.

\section{INTRODUÇÃO}

Alice Vilas Boas, conhecida como Alice Guél, nasceu na periferia de Indaiatuba, interior de São Paulo. Sua carreira se estabeleceu no rap, gênero musical popular que aos poucos ganha o seu espaço na cultura nacional. Mesmo com um público historicamente estabelecido na periferia, majoritariamente entre homens e jovens, nos últimos 15 anos, principalmente por conta da internet e a diversidade dos meios de comunicação, o rap alcançou as classes sociais médias e altas e se democratizou como um gênero plural quanto ao seu uso, acesso e produção.

Por meio de grupos coletivos e produções independentes, a internet disponibiliza hoje, aos agentes do rap, caminhos mais dinâmicos de divulgação, organização e acesso à cultura. Abrem-se, então, 
possibilidades para uma nova geração de artistas, músicos e Mc's $^{1}$ dos mais diversos locais, assuntos e estéticas. Uma antiga geração conhecida pelo posicionamento contrário à associação do rap aos grandes meios de comunicação (TV e gravadoras), com extremas dificuldades financeiras para produzir e divulgar o material dá espaço para artistas cada vez mais populares nas mídias sociais, advindos de classes sociais e gêneros diversos. Essa nova escola do rap administra produções e marcas independentes, se apropria dos espaços midiáticos entre programas televisivos e online. Alice Guél se constitui como parte dessa nova geração do rap que propõe novos discursos, novas estéticas/performances, abrangendo um novo público. Como veremos, ela dispõe seu corpo, sua voz e sua escrita para um novo tempo: faz do erótico sua política e do seu corpo sua religião.

O artigo seguirá em quatro momentos distintos: 1) apresentação da vida e obra de Alice Guél, através de vídeos e entrevistas; 2) desafios e tensões que as recentes discussões sobre identidade de gênero reivindicam na cena cultural do rap, seguida de uma análise de como a rapper desenvolve sua teopoética, principalmente em seus EP's², 3) Alice no país que mais mata travestis (2017), e 4) Alice em frente ao espelho (2019). As duas primeiras partes desta reflexão estão devidamente conectadas com as análises finais, localizando o leitor ao contexto geral do rap, bem como a potência religiosa contida na vida e obra de Alice Guél.

Contudo, é necessário destacar que Alice não confessa nenhuma tradição religiosa específica, mesmo que os símbolos e referências demonstrem aproximações com um cristianismo evangélico. Na verdade, a afirmação do seu corpo - enquanto gênero, classe e raça - materializa um protagonismo singular de acesso ao sagrado, estabelecendo a partir dele um fazer político e poético referente de sua realidade social. Assim, é possível identificar em sua obra diversas imagens bíblicas em diálogo com seu corpo, sendo este corpo transgênero o locus da experiência que

Sigla para "Mestre de Cerimônia”, aquele que é responsável por conduzir o público através do canto ou da fala, a um tipo de comportamento de ânimo, seja em apresentações artísticas ou qualquer outro espaço.

2 Sigla para "Extended Play". Significa um projeto musical com mais de uma música, mesmo que pequeno para ser considerado um álbum. 
atribui valor e significado às experiências. Dessa forma, busca-se refletir, neste artigo, a abrangência da literatura poética não apenas enquanto lugar teológico, doutrinário ou dogmático de determinada religião. Compreendendo a teopoética enquanto um vasto campo dos estudos entre literatura e religião, seus variados modos de "leitura religiosa do texto literário" (Antônio CANTARELA, 2018, p. 194), analisaremos como a poesia de Alice Guél se apropria dos símbolos da religião e faz da literatura uma forma não-teórica de teologia (José BARCELLOS, 2000, p. 10). Sendo reducionista a tentativa de compreender a obra sem levar em conta os elementos religiosos. Tentaremos, então, problematizar e até mesmo expandir alguns aspectos da compreensão teológica tradicional, assim como refletir sobre o rap brasileiro.

\section{VIDA E OBRA}

Alice Guél lançou sua primeira música em 12 de outubro de 2017. Deus é travesti é a música que materializa - depois de um ano de pesquisas e apresentações - o começo de sua história no rap. Poucos meses depois, no dia 25 de dezembro daquele mesmo ano, lançou o seu primeiro EP Alice no país que mais mata travesti. Dois anos depois, em 2019, lançou o segundo trabalho: Alice em frente ao espelho. Há também alguns registros de videoclipes e outros projetos de sua autoria, porém, sua trajetória no rap ainda é recente. Consideramos, então, oportuna uma breve apresentação de aspectos da vida e da obra de Alice Guél, com o objetivo de familiarizar o/a leitor/a com o contexto de produção da sua poesia, não porque acreditamos só haver possibilidade de compreender o objeto literário a partir da sua autoria, mas pela oportunidade de refletir de forma inédita sobre a autora e seu trabalho no rap. Certamente, não se desconsidera o desafio de tal análise. Sendo o rap um gênero musical composto não só de texto, mas de sonoridade, ritmo e performance, a complexidade estética empenhada por Guél impõe a esta reflexão um caráter introdutório sobre o assunto.

Desde pequena, Alice Guél tem contato com diversas linguagens da arte. Em entrevista, ela relata que aos nove anos, sua madrinha lhe colocou para treinar futebol. Essa experiência se tornou, ao longo dos treinos, tediosa e sem funcionalidade, visto que não conseguia compreender muito 
bem a mecânica e as regras dentro do jogo (Alice GUÉL, 2017). Relata também que o local em que treinava junto com os meninos, separava-os das meninas ${ }^{3}$. Esportes "radicais" eram direcionados aos homens - onde o futebol se encaixava - e atividades mais "calmas" às mulheres (Alice GUÉL, 2017). Neste contexto, Guél se encontra com a dança, uma das atividades às quais as meninas daquele projeto eram automaticamente incentivadas. Com a curiosidade de saber como eram as aulas de dança e o que essas meninas faziam, enquanto ela mesma lidava com as suas dificuldades no futebol, Alice Guél diz: "eu lembro que uma vez eu fui, 'Ioki' doida assim, meio que fazendo a sonsa, 'ah, errei de lugar gente, na boba'. E comecei a fazer [dança]. Fiz uma aula de Jazz, daí todo mundo começou a falar que eu me dava super bem" (Alice GUÉL, 2017).

Guél esteve envolvida com "arte, dança e música” (Alice GUÉL, 2018) desde muito cedo. Permaneceu exclusivamente na dança até os 16 anos. A partir desse momento, começou a entender que a dança em si ainda não era o espaço mais adequado para tudo o que buscava expressar. Através da poesia, antes de chegar propriamente no rap, começou a desenvolver ideias para a construção de um álbum visual que envolvesse as diversas linguagens artísticas de que dispunha (Alice GUÉL, 2017). Alice conta que, enquanto escrevia a letra de As coisas vão mudar, poema que depois se tornou música, Rodrigo Campos, um amigo produtor, mandou um beat ${ }^{4}$ para ela, na intenção de saber se Guél tinha interesse de cantar algo naquela base instrumental. Passado um tempo desde aquele convite, ela diz: "eu tava ouvindo o beat no banheiro, e tava recitando o poema. E quando eu tava recitando o poema, eu comecei a tentar encaixar ele no beat. Aí, nossa, fiquei indignada! Consegui encaixar a música no beat" (Alice GUÉL, 2017).

Todo esse processo de busca por uma identidade artística aconteceu de maneira prática, entre performances e shows. Até “perceber

Alice Guél descreve as tensões e conflitos em relação à transsexualidade em sua infância: "Pra mim eu tava fantasiada de menino, até nove anos / Nove anos com uma fantasia quente, e pinicante” (Alice GUÉL, Intetrlude I, 2017b); "Vixe, que criança estranha! / O que tem entre as pernas é minhoca ou aranha?” (Alice GUÉL, Deus é travesti, 2017b).

4 Termo comum usado para denominar a base musical que acompanha as letras de rap. É a junção do instrumental, da batida, das colagens de músicas (samples) ou sons diversos que compõe uma música de rap. 
que na verdade não era um filme, não era só performance, era sim um EP" (Alice GUÉL, 2018a) de rap que gostaria de produzir. Não só neste primeiro trabalho, mas em todas os seus projetos, encontram-se experimentações audiovisuais e performatividades, tendo sempre como base de sua mensagem poética o rap e a performance. Na ânsia de encontrar os meios adequados para comunicar a complexidade de seus anseios, Guél diz: "Eu queria ir além, além [...] da batida que as pessoas tavam propondo pra mim fazer, sabe? Eu queria talvez, quem sabe, fazer minha própria batida, pra eu poder mostrar com o meu corpo o que que eu queria falar" (Alice GUÉL, 2017).

A necessidade que Alice Guél tem de falar, denunciar e expor a sua realidade enquanto corpo transexual, negro e periférico, finalmente encontra lugar na cultura hip-hop. Os quatro elementos que formam esse movimento ( $\mathrm{Dj}$, Mc, grafite e B-Boy), em suas diversas formas de expressão, têm como característica transmitir uma mensagem socialmente engajada e que transcreva a realidade do/a sujeito/a e suas dimensões. O rap (Rhythm and Poetry/Ritmo e Poesia), compreendido neste artigo como "literatura oral urbana" (Marcus SALGADO, 2015, p. 151), evoca uma presença social. Sua essência se dá entre ritmo (corpo, performance e musicalidade) e o fazer poético (oralidade, narrativa e ficcionalidade). Abordando assuntos diversos, o rap carrega um princípio transgressor - próprio de sua origem negra e periférica - ante às ordens sociais autoritárias e desiguais, resgatando a voz, o corpo e a imaginação poética dos/as excluídos/as (Roberto OLIVEIRA, 2015, p. 36). O rap contém um "esforço pragmático em relacionar forma estética e realidade social" (Marcus SALGADO, 2015, p. 154), consolidando uma "forma de agenciamento comunitário e de resistência cultural” (Marcus SALGADO, 2015, p. 153).

Diversos grupos marcaram a história do rap brasileiro justamente por se colocarem como "Voz Ativa"' da população negra e periférica do país. O grupo Racionais Mc’s, por exemplo, antecede não só Alice Guél, mas como diversos Mc's. Desde a sua origem, em 1988, seu discurso ajuda a construir a identidade, a luta e até mesmo imaginário religioso ${ }^{6}$

Racionais Mc's, “Voz ativa”, Lp Escolha seu caminho (São Paulo, Boogie Naipe, 1992).

6 Ver: "O evangelho marginal dos Racionais Mc's" de Acauam Silvério de Oliveira, no livro Sobrevivendo no Inferno. São Paulo: Companhia das Letras, 2018. 
do "sujeito periférico" (Tiajarú D’ADREA, 2018). Guél sinaliza que o seu caminho se desenvolve a partir de referências como esta, ao destacar que o rap entrou em sua vida por influência de sua mãe: "que ouvia 105 FM 24h por dia, especialmente quando começava o [programa] 'ESPAÇO RAP' onde tocava Expressão Ativa, Ao Cubo, Thaíde, Racionais" (Alice GUÉL, 2018). Os grupos Expressão Ativa e Mv Bill também estão entre suas referências, além de destacar sua preferência por raps que tinham uma "ligação com o rap meio religioso" (Alice GUÉL, 2018a), o que ajuda a compreender um pouco da relação com elementos e figuras religiosas, tanto em sua poesia como em suas performances.

A partir dessas influências, Alice Guél faz do seu rap "um portal de contato direto com realidades de corpos periféricos que muitas vezes (quase todas) não tem peso, importância e significância social alguma" (Alice GUÉL, 2018). Foi a partir do rap que ela começou, em suas palavras, a "entender um pouco do quanto poderia dizer, da potência que a [sua] voz tem, sabe? A minha voz que nunca foi ouvida por ninguém, em nenhum espaço" (Alice GUÉL, 2017a). Guél nasce “em meio nessa necessidade de falar coisa que acontece sobre nós, corpos LGBTs, pretos e periféricos, que normalmente não passa na mídia, em outros lugares" (Alice GUÉL, 2018a).

\section{TENSÕES SOBRE GÊNERO NO RAP7}

Nota-se, no rap brasileiro, como na maioria dos espaços desta sociedade, o protagonismo masculino e sua normatividade quanto ao estabelecimento de padrões em relação à identidade de gênero e sexualidade. Não que as mulheres não estivessem presentes desde o início do movimento hip-hop, influenciando, desenvolvendo e produzindo em todas as linguagens que caracterizam essa cultura ${ }^{8}$. Fato é que

\footnotetext{
Este artigo não tem a intenção de abordar ou debater criticamente teorias e conceitos sobre as identidades de gênero. O objetivo não é fazer uma escolha metodológica específica, mas refletir aspectos históricos e estéticos, além dos desdobramentos teopoéticos, a partir do rap brasileiro.

8 O documentário "Nos tempos da São Bento" apresenta depoimentos e filmagens das mulheres que estavam presentes no início do movimento hip-hop em São Paulo, principalmente através do rap e da dança (b-girl). Ver em: https://www.youtube.com/watch?v=z8FtlypGeVs. Acesso em: 18 mai. 2020.
} 
a participação destas sempre esteve invisibilizada ou subalternizada, tanto pela estrutura patriarcal que nega/direciona a participação da mulher nos espaços sociais e culturais que lhes convém, quanto pelo machismo intrínseco no comportamento, na linguagem e nas relações simbólicas que a heteronormatividade cis $^{9}$ e binária ${ }^{10}$, impõe às outras formas de construção de gênero.

Nas primeiras coletâneas de rap produzidas no Brasil, por exemplo, das 17 músicas presentes em Hip-hop cultura de rua (1988) e Consciência Black Vol. 1 (1989), apenas neste último consta a presença feminina, na música Nossas dias, cantada por uma mulher chamada Sharylaine. Grupos e nomes considerados como referência na história do rap nacional, como Thaíde e Dj Hum, Ndee Naldinho e Racionais Mc's, contribuíram não somente para a evolução e popularização do gênero musical, sua estruturação política e estética, mas também com a estigmatização das mulheres, sua hipersexualização e discursos de ódio contra mulheres e comunidades LGBT ${ }^{11}$, consolidando uma postura machista sobre o ethos feminino, entendido como propriedade masculina, culpada por seduzir os homens e pelo seu mau comportamento:

"Mulher e dinheiro, dinheiro e mulher / Sem os dois eu não vivo qual dos dois você quer / Mesmo que isso um dia, traga problema / Ir pra cama sozinho, não vira esquema/ Segunda (a Patrícia) / Terça, a (Marcela) / Quarta, a (Raissa) / Quinta, a (Daniela) / Sexta, a (Elisângela) / Sábado, a (Rosângela)/E domingo? É matinê, 16 o nome é Ângela"’2.

"Mestiça, negra ou branca, sempre sai uma vagabunda" / "Tire da cabeça que mulher é incapaz / Capaz ela é, e mentirosa o quanto quiser / Nunca se sabe o que se passa na cabeça dela / Muda a cada instante de cão pra cadela"'ı.

9 O termo "cis" se refere à pessoa que identifica o sexo de nascença com o seu gênero.

10 O termo "binário" se refere à ideia de que existem dois gêneros: homem e mulher.

1 Neste artigo, a sigla LGBT serve para designar o grupo de pessoas lésbicas, gays, bissexuais, transexuais e todos os outros gêneros não-binários.

12 Racionais Mc's, “Estilo Cachorro”. Álbum Nada como um dia após o outro dia (São Paulo, Boogie Nipe, 2002).

13 Racionais Mc's, “Parte II”. Álbum Raio-X do Brasil (São Paulo, Zimbabwe Records, 1993). 
"As mina geme crime, não o creme"

"Ela me chame pro cacete e já começa a dar porrada / Xingo ela de piranha, de bico de galinha / Digo lugar de mulher meu bem / É na cozinha"15.

"Com muita alegria ele roda a cidade / Conhecendo pessoas, fazendo amizade / Andando pela rua veja quem encontrei / Meu vozinho caduco, batendo num gay" ${ }^{16}$.

"Não quer ser considerada símbolo sexual / Luta pra chegar ao poder, provar a sua moral [...] Seu jeito vulgar, suas ideias são repugnantes / É uma cretina que se mostra nua como objeto / É uma inútil que ganha dinheiro fazendo sexo" 17 .

"Vocês consagraram o estilo cachorro"18.

Direcionando para a nossa discussão, Pepeu, rapper paulistano conhecido por fazer parte do inicio do rap brasileiro (um dos seus sucessos foi Nomes de meninas), relata em uma de suas músicas a história de um pedido realizado pelo telefone, por uma garota de programa. Depois que o personagem pede "uma loirinha de olhos azuis, com um corpo bem bonito" que fizesse "passar mal”, nas palavras de Pepeu: "Veio um negão", que na música, se interessou, "gostou” do personagem de uma forma sexualizada, dando a entender que o rapaz negro gostaria de se relacionar sexualmente com aquele que fez o pedido. Diversas análises poderiam ser feitas a partir dessa canção: as dimensões simbólicas do machismo, hipersexualização do corpo negro ou a construção da masculinidade. Mas, certamente, poderíamos nos afastar da reflexão aqui proposta. O que se pode dizer brevemente desta letra é que ela reflete uma

14 Thaíde, "Viagem na rima". Álbum Assim caminha a humanidade (São Paulo, Trama, Brava Gente, Matrca, 2000).

15 Ndee Naldinho, “E essa mulher? De quem é?”. Álbum Só porque sou favelado (São Paulo, TNT Records, 1991).

16 Pepeu, "Hey vovô". Album The Culture of Rap (São Paulo, Kaskata's Records, 1989).

17 Racionais Mc's, “Mulheres vulgares”. Álbum Holocausto urbano (São Paulo, Boogie Naipe, 1990).

18 Racionais Mc's, “Estilo Cachorro”. Álbum Nada como um dia após o outro dia (São Paulo, Boogie Nipe, 2002). 
normatividade heterossexual e masculina presente na história do rap, um comportamento de negação e reconhecimento não só da mulher, mas também da diversidade sexual e suas vastas possibilidades. Assim, compreende-se que o rap brasileiro acumula um histórico complexo e discutível em relação às questões de gênero, sendo possível suspeitar da grande influência desse estilo musical não só na formação política de uma juventude engajada, mas também a compreensão limitada e preconceituosa sobre outras identidades de gênero não-binárias: "O rap é uma foto $3 \times 4$ da nossa cultura. E ela é machista, homofóbica, reacionária. Mas o rap é grande, e a Internet faz nascer novos mundos em um clique" (Rico DALASAM, 2016, s/p).

Diante desta realidade histórica, se fortalece um novo horizonte dentro do hip-hop. Uma pluralidade de vozes forjou seu espaço e se apropriou da literatura oral urbana, problematizando a cultura machista e patriarcal na qual o gênero se desenvolveu. Tanto mulheres como a comunidade LGBT estão disputando cada vez mais a narrativa, a produção e a mídia do rap junto aos homens. Karol Conká, Flora Matos, Drika Barbosa, Clara Lima, Tássia Reis se somam entre as diversas mulheres que tem trazido ao rap brasileiro a oportunidade repensar seu discurso ${ }^{19}$. Junto às mulheres, e de forma recente no Brasil ${ }^{20}$, grupos e rappers oriundos da comunidade LGBT têm rompido os padrões heteronormativos estabelecidos dentro e fora do rap, colocando suas pautas de forma contundente e contemporânea. Somam-se a esse segundo grupo Rico Dalasan, Linn da Quebrada, Quebrada Queer, Jup do Bairro, Mc Dellacroix, Rap Plusize, Ventura Profana, Alice Guél, entre outros/as artistas.

Toda essa recente tensão sobre identidade de gênero, tanto na sociedade quanto no rap, atrai não só os olhares de pesquisadores acadêmicos ${ }^{21}$. Além desse movimento abrir possibilidade para novos

19 "Hip-Hop é arte que salva vidas/Machismo é vírus, somos a vacina". Drika Barbosa, In: "Poetas no topo 3.1". Single Poetas no topo 3.1 (Rio de Janeiro, Pineaplle, 2017).

20 "Hip hop LGBTQIA - tendência que surgiu no final da década de 90 nos EUA, com o surgimento de artistas LGBTQIA da cultura Hip hop" (Tiely QUEEN, 2018, p. 465)

21 Ver trabalhos e artigos acadêmicos sobre rap e gênero em: Tiely QUEEN, 2018; Paula CLARO e Ariane PEREIRA, 2019; Sandra SANTOS, 2012; Ayni ARAUJO, 2016; Felipe FERREIRA e Vera CRISTÓVÃO, 2019. 
Mc's ${ }^{22}$ oriundos das comunidades LGBT, a discussão trouxe um novo olhar para dentro do movimento hip-hop:

Depois de quarenta anos de Cultura Hip Hop, muitas dessas pessoas [LGBTQIA+], apesar das inúmeras violências que sofrem, estão protagonizando a cena cultural em várias cidades pelo mundo e trocando os alicerces culturais padronizados, que a sociedade insiste em manter, por estruturas sociais sem limitações. (Tiely QUEEN, 2018, p. 463-464)

A luta por afirmação da diversidade e liberdade dentro do rap fortalece a pauta de gênero e sua mensagem pela vida (Tiely QUEEN, 2018, p. 466). Palavras de ordem como "Vai ter bicha no rap sim! E eu nem sou o primeiro" 23 ou "Os mano fecha a mão quando vê as trava ${ }^{24}$ entrar" (Alice GUÉL, 2017b) não passam despercebidas. Mano Brown, integrante do grupo Racionais Mc's, conta em entrevista que, ao ouvir o começo da música Estilo cachorro (já mencionada) em uma de suas apresentações recentes, pediu (com certa rapidez) para que aquela parasse de trocar, pois em sua visão, não fazia mais sentido fomentar aquele tipo de discurso ${ }^{25}$. Criolo, outro rapper paulistano, ao regravar em 2016 um disco de 2006 (Ainda há tempo) mudou algumas palavras que considera hoje inadequadas às novas discussões de gênero ${ }^{26}$, no

22 “É legal que a gente não leva só representatividade pras travestis, né. A gente leva representatividade pras travestis, pras travestis brancas, pras travestis pretas, pras travestis indígenas, pra todas as travestis, então, tipo, tem um lance de empoderamento travesti, empoderamento negro que a gente leva, nas nossas músicas, que é importante, assim. Porque a negritude é importante pra qualquer pessoas negra no Brasil, se reconhecer enquanto negra pra afirmar isso, que é uma questão de empoderamento, é uma questão de resistência. Então, tipo, não é só ser travesti, não é só ser preta, não é só ser periférica, é ser travestis, é ser preta, é ser periférica, é ser pobre, vários âmbitos que a gente tá indo, a gente representa muitas pessoas" (Alice GUÉL; Mc DELACROIX, 2017).

23 Quebrada Queer, “Quebrada Queer”. Álbum Ser (São Paulo, RapBox, 2018).

24 A palavra "trava” é um sinônimo e uma abreviação da palavra travesti.

25 "Tem música que eu não canto mais. Para, nós vamos ser linchado [...] se liga no momento do Brasil” (Mano BROWN, 2018).

26 Criolo fala à revista TRIP que já usou algumas rimas e palavras preconceituosas por ignorância: "Era ignorância minha, né? Por falta de conhecimento da minha parte, usei em algumas músicas esses jargões populares, alguns apelidos e palavras que não fazem sentido algum e só magoam as pessoas" (CRIOLO, 2016). 
qual o rap, como um movimento cultural em constante transformação, também precisa se reexaminar e fazer uma autocrítica ${ }^{27}$.

\section{A OBRA GUELIANA}

Segundo a ONG Trangender Europe, entre 2008 e 2016, o Brasil matou 868 travestis e transexuais. Esse número subnotificado representa mais que o triplo do México, que ficou em segundo colocado com 256 mortes (CORREIO BRASILIENSE, 2016). Diante desta situação de extrema vulnerabilidade à qual pessoas transexuais são submetidas neste país, nasce o EP Alice no país que mais mata travestis. O álbum pretende ser uma releitura simbólica da obra já conhecida Alice no país das maravilhas, de Lewis Carroll. É preciso ter em mente algumas características do livro de Carroll, como a lógica estética absurda, seus diversos enigmas ou acontecimentos surreais. Alice Guél junta sua história e seu próprio nome ao imaginário da personagem infantil do livro, que percorre um caminho de inúmeras descobertas, enfrentando dilemas de um mundo fantástico, através de personagens e cenários lúdicos de um país das maravilhas. Guél tem o objetivo de recontar tal "história pelo o olhar da "Alice”" que vive não "no país das maravilhas", mas "no país que mais mata travestis". Esta proposta se estabelece como um duplo sentido: 1) reconhece a potente autonomia da personagem Alice de Carroll, como 2) a representação de Alice Guél, como personagem e protagonista de um mundo confuso, caótico, com tons de ludicidade, como o apresentado no livro, apesar de um novo contorno social, de gênero e religioso que são próprios da construção que faz do seu Brasil.

Ideia parecida acontece no segundo EP de Alice Guél, que se chama Alice em frente ao espelho (2019). Esse título, mesmo que não mencionado explicitamente no álbum, é uma alusão a segunda obra de Lewis Carroll Alice Through looking glass, em português Alice através do espelho. Nesta obra, a personagem Alice novamente encara uma aventura onde a figura de um espelho se torna o portal e a mediação entre sua nova missão e um mundo fantástico de formas, tamanhos e ordens diferentes. A obra de Alice Guél se torna uma metáfora para

27 "Que o rap é machista, nóis tá sabendo / Mas não é por que nasceu machista, que ele tem que continuar sendo". Rashid, "Abre caminhos”. Single Abre caminhos (São Paulo, AWLAWD, 2017). 
uma realidade mais profunda que se desvela ao longo do álbum. O espelho que Alice Guél tem à sua frente é o portal para uma realidade violenta, onde o cotidiano de uma mulher trans é descrito em detalhes, sendo sua missão, estabelecer um novo tempo e um novo templo de dimensões místico-políticas. Alice em frente ao espelho é o prenúncio do dilúvio, uma nova humanidade. Sua missão é passar por esse portal, sobreviver à morte sempre iminente e anunciar destruição e salvação contra estruturas antigas: "Só se salva quem crê na trava / Só se salva quem entra na arca / Só se salva quem tem a marca"28.

Alice Guél, como a maioria dos/as rappers, tem no seu horizonte um discurso político contundente, intrínseco à sua poesia: "o movimento negro me ouviu, os LGBTs me ouviram” (Alice GUÉL, 2017a). Mas sua preocupação artística extrapola os limites de uma ideologia panfletária, mostrando um cuidado estético em toda a sua performance a partir da confluência entre reflexão ética, estilo e religiosidade: "Eu piro muito em mostrar as sonoridades que a gente não costuma ouvir, junto com a performance corporal que a gente não tá acostumado a ver, levado por um corpo que ninguém tá acostumado a ver também" (Alice GUÉL, 2017). Guél produz e experimenta o sentido do som, molda-o a partir do seu corpo e atribui significados plurais sobre sua existência:

A gente tem uma arte, sabe? Travesti fala de um jeito peculiar, travesti se comporta de um jeito "peculiar". Tipo, existe mesmo uma arte que é travesti, no se vestir, de como a gente se fala, se comporta, escreve, se comunica, se ama, e é isso que eu quero mostrar pras pessoas. (Alice GUÉL; Mc DELLACROIX, 2017)

A obra gueliana se constrói na experiência do corpo. Perpassa a condição de um corpo de sentido místico, erótico, politicamente transexual. Seu corpo é lugar hermenêutico do seu rap. Sua preocupação estética passa não só pelo corpo enquanto atividade artística imanente, mas o corpo enquanto acesso poético de uma experiência transcendente, preocupada com a realidade última, com o sagrado. Seu poema reflete o seu mundo. Faz dele uma reflexão subjetiva de si mesma, ora

28 Alice Guél, “Dilúvio”. EP Alice em frente ao espelho (São Paulo, Trava Bizness, 2019). 
com traços de um testemunho pessoal, ora distante, livre ou além das categorias fixas de qualquer estrutura literária fechada. Pode-se dizer que o seu "poema se alimenta da linguagem viva de uma comunidade, de seus mitos, sonhos e suas paixões, ou seja, de suas tendências mais secretas e poderosas" (Octávio PAZ, 1982, p. 49-50).

\subsection{Alice no país que mais mata travestis}

O EP Alice no país que mais mata travestis tem 6 faixas, sendo 3 músicas e 3 "intervenções que ligam as músicas como um chiclete grudento, dramático e viciante” (Alice GUÉL, 2018). Entre esses interlúdios estão alguns trechos de áudios e experimentações sonoras diversas (barulhos, vozes não identificadas, remixes de músicas e instrumentais). A primeira música As coisas vão mudar, apresenta um discurso de empoderamento da mulher trans, negra e periférica: “Não estranha, não, viu? / É o comecinho tio / Vocês não mata os homo / Estupra as mana até o fim? / Então, agora aceita / Abaixa o pau, a bola e a mão pra mim". A linguagem sexualmente explicita é proposital, marca de forma incômoda e cotidiana, aspectos da experiência sexual transexual, muitas vezes vivida entre violência, preconceito e prazer: "Só quer me comer se for no beco escuro / Mas tu não me ganha só com esse seu pau duro / Não é você quem diz: - Eu não pego travesti / Alguém por favor tira logo ele daqui".

As outras duas músicas Deus é travesti e Meu templo, revelam aspectos de uma poética erótica com elementos e figuras de uma experiência religiosa cristã. $O$ acesso a Deus na obra gueliana se dá a partir do corpo transgênero, sendo a sexualidade e a linguagem erótica o lugar poético de revelação/relação com sagrado. O filósofo Georges Bataille em seu livro O Erotismo, diz que o ser humano é o único animal que faz da prática sexual de reprodução uma atividade erótica, ou seja, não é simples reprodução de espécie, mas um ato racional que busca prazer e realização. $O$ ato sexual relacionado à atividade erótica se estabelece como desejo de continuidade (transcendência) do qual o filósofo diz atrelar-se à nossa realidade descontínua (imanente). Bataille afirma que: "O espermatozoide e óvulo são, em seu estado elementar, seres descontínuos, mas se unem e, em consequência, uma continuidade se 
estabelece entre eles para formar um novo ser a partir da morte" (Georges BATTAILE, 2017, p. 38). Esse desejo de continuidade determina três aspectos do erotismo: o erotismo dos corpos, o erotismo dos corações e o erotismo sagrado (Georges BATTAILE, 2017). A questão envolvida no erotismo é a substituição do isolamento existencial do ser descontínuo por uma experiência de continuidade profunda estabelecida através do corpo, do coração e do sagrado, efetivada na experiência mística, sexual-erótica e no sentimento amoroso.

A música Deus é travesti, por exemplo, desenvolve-se entre elementos, frases e figuras de linguagem que expressam o desejo erótico do eu-lírico, em estabelecer uma experiência de continuidade, proporcionada pela confluência entre o erotismo dos corpos e o erotismo sagrado. A poesia começa com uma paráfrase da oração cristã conhecida como Pai-nosso: "Travesti nossa que estais no céu / Santificado seja o nosso nome”. Há, nesses versos, uma reivindicação de uma experiência religiosa que passa, necessariamente, pelo pertencimento de uma identidade social de gênero, religiosamente marginalizada, atribuindo significado e valor positivo ao sujeito travesti; além de trocar a posição hierárquica já pré-estabelecida pelo cristianismo entre Deus e os homens. Neste caso, a divindade é destituída ou repartida de sua posição sagrada, estando diante de um sujeito transexual, também sagrado. Ao fazer sua oração à Deus travesti, Guél afirma que a santidade não se encontra no nome divino, nem que os planos terra e céu sejam determinantes para estabelecer a noção de sacralidade, mas que o nome e a vontade das travestis que estão na esquina, também são dotados da mesma sacralidade: “Alice, Cecília, Eloá, Érika, Olga / Amara, Ela, Ametista, Alicia / Seja feita a vontade das vadias / Assim na Terra como em qualquer outra esquina / A woman"29.

A música continua narrando dores, infância e a inadequação de um corpo transexual negro e periférico: “Um preto favelado, traveco, à lá gazela" ${ }^{\prime 3}$. Em dado momento da canção, é apresentado um conflito entre o seu de gênero com "um lugar que vendia mudança": igreja. A letra diz que com muitas preces, "joelho no chão” e "jejum”, foi dedica-

29 Alice Guél, “Deus é travesti”, EP Alice no país que mais mata travestis (São Paulo, Alice Guél, 2017).

3o Alice Guél, “Deus é travesti”, EP Alice no país que mais mata travestis (São Paulo, Alice Guél, 2017). 
do para a compreensão de si, em busca de uma solução religiosa que a ajudasse passar por tais transformações. No final, todo aquele conflito levado em oração, na verdade, era feito em nome da "deusa travesti", vista como "a deusa dos corpos que querem resistir / Deus é travesti / A deusa dos corpos que querem existir" ${ }^{31}$. Neste clamor por sobrevivência, seja por conta da morte violenta ou a violação sexual/erótica do seu corpo, dialeticamente o ser é diluído e alcança sua plenitude, "pois a morte tem o sentido de continuidade do ser" (Georges BATAILLE, 2017, p. 37). A existência de Alice Guél, enquanto corpo transgênero dotado de poesia, deseja vida através do estabelecimento de uma experiência de "continuidade" e união com o seu Deus travesti: "Mãe nossa que estais no céu / Ajude as travestis que estão passando fome / Venha ver o nosso reino / Pra que entenda a vontade das vadias / Aqui, em casa, na igreja, na rua / Em toda e qualquer esquina" ${ }^{32}$.

Os corpos travestis, de que fala Alice Guél, se comportam como corpos erótico-heréticos. Segundo Rubem Alves, além da liberdade em estabelecer sua própria verdade, "o corpo só se move ao som do desejo e do erótico" (Rubem ALVES, 2009, p. 76). Da experiência de Guél nasce uma teopoética marginal que nasce do corpo, do desejo e da imaginação. Desses corpos sacrificados nascem inúmeras possibilidades de uma experiência mística dos que nada possuem a não ser o próprio corpo e imaginação (Rubem ALVES, 2009, p. 52). A presença do corpo trans problematiza verdades, potencialmente escandaliza a religião hegemônica e aponta novos caminhos de esperança. Consequentemente, sua heresia tem um potencial libertador, uma vez que ele é um discurso político contra poderes e ideologias dominantes (Danilo MENDES, 2019, p. 30). A professora Jaqueline Gomes de Jesus, em seu livro Transfeminismo: Teorias e Práticas, diz que o "transfeminismo" (conceito ainda em construção), responde às categorias sexistas, intelectuais e racistas da sociedade, bem como do feminismo biológico clássico, que não levava em conta a luta e as pautas das mulheres transexuais (Jaqueline JESUS, 2014). Esse conceito nos ajuda a compreender a potencialidade do que temos tratado aqui como corpo erótico-herético transgênero. Já na apresentação da obra, Jesus afirma:

Alice Guél, "Deus é travesti”, EP Alice no país que mais mata travestis (São Paulo, Alice Guél, 2017).

32 Alice Guél, “Deus é travesti”, EP Alice no país que mais mata travestis (São Paulo, Alice Guél, 2017). 
O transfeminismo reconhece a intersecção entre as variadas identidades, identificações dos sujeitos e o caráter de opressão sobre corpos que não estejam conforme as ideias racistas e sexistas da sociedade, de modo que busca empoderar os corpos das pessoas como eles são, deficientes ou não, independentemente de intervenções de qualquer natureza; ela também busca valorizar todas as expressões sexuais das pessoas transgênero, sejam elas assexuais, bissexuais, heterossexuais, homossexuais ou com qualquer identidade sexual possível ${ }^{33}$.

"Deus é travesti" pode ser entendido enquanto um conceito teopoético que nos ajuda perceber algumas características que formam esse corpo social/místico travesti e marginalizado que deseja, passa fome, sofre, ora, trabalha, cuida, transgride e é transgredido. Guél relata, em entrevista, que a "vontade das vadias", por exemplo, não é simplesmente um corpo "safado" e "malicioso", mas o próprio desejo de ser "reconhecido enquanto corpo. Essa é a vontade das vadias" (Alice GUÉL, 2017). A contravenção da afirmação de Deus enquanto travesti também é explicada por ela: “Deus é travesti porque sou eu [eu sou]. Alice Guél voltou porque o apocalipse já foi. Eu voltei. E voltei pra dizer que Deus não é cis" (Alice GUÉL, 2019). Assim, o lugar do corpo é reivindicado não só como igual, mas como revelação crística, messiânica, instrumento erótico em busca de uma experiência mística onde Deus encarna a transgeneridade:

A [música] Deus é travesti é as prostitutas, Deus é travesti são os moradores de rua, Deus é travesti são as mulheridades, não só as muIheres, as mulheridades. As bichas afeminadas, as trans não binárias, afeminades, todas essas mulheridades. Deus é travesti é negritude, Deus é travesti é os corpos deslocados, os corpos estranhos. Deus é travesti também cuida muito das pessoas do submundo, sabe? Das pessoas que tem um outro estilo de vida a não ser só esse, né, cristão, católico (Alice GUÉL, 2017).

A poesia de Alice Guél possui um “contágio profano”, pois devolve ao uso profano (imanente) aquilo que havia sido santificado à trans-

33 Jaqueline Jesus. Transfeminismo: Teorias e Práticas. Rio de Janeiro: Metanoia, 2014. Apresentação, p.3. 
cendência (Giorgio AGAMBEN, 2007). Há nesta poesia uma identidade profana e contestadora vinda de um corpo erótico-herético. Esse posicionamento é, ao mesmo tempo, uma forma de criticar o fundamentalismo religioso do qual os/as transexuais são alvo, mas, também, de consagrar o corpo travesti como possibilidade positiva para estabelecer uma relação interior/mística com Deus, em igualdade aos outros corpos, compartilhando também da imagem e semelhança divina. Tal corpo poético nos conduz "à eternidade, nos conduz à morte e, pela morte, à continuidade: a poesia é a eternidade" (Georges BATAILLE, 2017, p. 48).

A música Meu templo compartilha também da centralidade do erotismo dos corpos enquanto característica poética. Alice Guél faz uma relação direta do seu corpo como templo, relacionando-se com a passagem bíblica em que o apóstolo Paulo afirma que o corpo deve ser "o templo do Espírito" (1Co 6.16-20). Alice Guél, então, propõe um outro tipo de Templo e a presença de um outro tipo de Espírito: “O meu templo tem cara de desejo, tem / O meu templo tem cheiro do pecado, tem / O meu templo tem carência e saudade / O meu templo tem simplicidade". As características que Alice Guél apresenta sobre a sua experiência enquanto corpo nos provoca. A comparação poética feita entre um corpo paulino "Templo do Espírito" é contraposto com um corpo travesti "Templo do pecado", que deseja, que é carente e, ao mesmo tempo, simples. Assim, é possível observar a proposta de um corpo humano sincero, que nutre uma espiritualidade mais profana que sagrada. Em uma apresentação, Guél discorre a respeito desse corpo:

Palmas pra essas 'corpas' estranhas. Cuidem bem delas. Esse é o nosso templo, a nossa casa. É aonde a gente faz tudo acontecer. Não foi isso que 'Deise' planejou pra gente, sabe. Então reconheça e cuida do seu templo, que tem muita gente torta querendo entrar, invadir o seu rolê, pra te usar, quebrar seus vasos, bagunçar sua casa, e depois não vai voltar nem se quer pra perguntar se precisa de alguma fita, sei lá. Então cuide, cuide bem (Alice GUÉL, 2019),

Esse corpo/templo com desejo, com cheiro do pecado, com carência, com simplicidade, se coloca em igualdade ao templo sagrado do Espírito. Alice Guél reivindica ao seu corpo a paridade com a revelação bíblica, e 
se apropria da Bíblia como fonte de imagens, metáforas e construções poéticas. A linguagem religiosa é utilizada como símbolo, sarcasmo e metáfora para uma crítica contrária à heteronormatividade compulsória e à teologia tradicional que nega a experiência transexual e enclausura a experiência da fé aos templos e às interpretações bíblicas fundamentalistas feitas por homens. Aqui, o corpo transgênero é essencial para a elaboração teopoética. Ele problematiza não só preconceitos e padrões religiosos, mas propõe uma revisão da teologia cristã, abrindo lugar para a experiência de Deus a partir do corpo travesti. Para isso, o pedido de Alice Guél é explícito: “Transicione seu Deus, se transicione todos os dias. Transicione sua arte todos os dias e de novo, e de novo, e de novo" (Alice GUÉL, 2019). A palavra transicione não significa apenas mudança/transformação ou processo em andamento. O termo diz sobre a transição, um processo comum onde pessoas trans assumem que o sexo biológico não corresponde com a sua identidade de gênero (Jaqueline JESUS, 2014). "Transicione seu Deus", além de ser um chamado a novas perspectivas de experiências sagradas, é uma proposta de "mudança" de gênero do próprio Deus. Observa-se que Alice Guél, mesmo sem uma formação teológica formal, se alinha através de sua experiência, com aquilo que a teóloga Marcela Althus-Reid (2001) propõe como sua teologia indecente, para que Deus possa encarnar, assumir e transicionar formas, gostos, gestos, gêneros e desejos dos corpos oprimidos.

Esta música termina com um verso que se repete como um mantra: “Transar, gozar, amar, viver". Tal desejo se mistura entre sexo, prazer erótico e a realização do amor e, sem a experiência, não se poderia falar tanto do erotismo quanto da religião. O erotismo responde à interioridade do desejo, ele é a própria experiência interior. O erotismo poético é a possibilidade do eu-lírico de se perder de si mesmo em busca de uma experiência transcendente (Georges BATAILLE, 2017), pois entre a "sensualidade e o misticismo, que obedecem a princípios semelhantes, a comunicação sempre é possível” (Georges BATAILLE, 2017, p. 274).

Alice Guél termina outra de suas apresentações da música Meu templo, dizendo:

Olhem pra mana que tá do seu lado e diga o quão importante ela é na tua vida. Isso aqui não é um show, um ato político, é uma cele- 
bração, uma unção, é um teretete. Nossas vidas são muito caras, as nossas vidas são muito caras. Cuidem das suas preciosas, cuidem das suas irmãs. Coloquem 1, 2, 3, 4, 5 dedos no edi [anus] que é ótimo. Vamo chupar buceta que é maravilhoso, tá bom? Buceta também se chupa, viu? Só um detalhe. Vamo votar conscientemente pra que a gente possa chupar mais bucetas. Ele não, ele nunca, ele jamais. Eu profetizo que ele nunca chegararararais. Não vai se concretizar. Não tá permitido. Essa terra é nossa, esse lugar é nosso, a rua é nossa, esses lugares são nossos sim, não vão deitar. A gente é livre pra caralho, pra caralho. Se permita se conhecer hoje quando chegar em casa, é sério. Não vão deitar a gente aqui não (Alice GUÉL, 2019).

\subsection{Alice em frente ao espelho}

Alice em frente ao espelho (2019) é o último trabalho lançado por Alice Guél. Para compreender um pouco mais a mensagem do seu rap teopoético, é preciso ter em uma espécie de cosmogonia contada por Guél em uma apresentação recente após a gravação deste álbum:

Há muito tempo atrás, existia uma terra, um espaço que foi criado por uma Deusa. Ele era um espaço feito por nós e para nós. E no meio do caminho, algumas coisas foram perdendo um pouco de sentido e acabou se tornando a base de ego, dinheiro, muitas vezes dólar... sobre seguidores, sobre quantidade. E isso meio que foi fazendo o espaço aonde Deise havia criado, num espaço de conflito. Deise muito chateada, triste, com a obra que ela havia feito, ficou pensando e matutando o que que a gente deveria fazer a partir dali. Eis que então, ela começa a reparar que, mesmo o cheio de tantas coisas desnecessárias e fora do lugar, existia sim aquelas de coração realmente bom. Aquelas que entendiam o real sentido de empatia e de afeto, de intimidade. Deise então decide que se restaure tudo de novo, se refaça tudo de novo. E ela pede pra que essa mulher, crie então uma nova arca, crie então um novo espaço, e que convide e chame todos os corpos transvestisgeneres negras, deslocados, (?), pra entrar nessa arca, e que juntes, assim, nós possamos construir uma nova humanidade. A gente precisa construir uma nova humanidade, porque que já está, já é falido, já não serve, já não nos cabe, não nos pertence mais. Dentro dessa arca me deparo então, mais uma vez: em frente ao espelho (Alice GUÉL, 2020). 
Esta história contada por Guél pode ser considerada como preambulo imaginativo da obra, podendo ser localizada até mesmo antes da primeira faixa do disco. Esse relato cosmológico pode ser considerado como uma paráfrase do relato bíblico, do livro de Gênesis, onde se mostra a criação do mundo na concepção judaico-cristã. A diferença do relato de Alice Guél são as personagens, os significados e o de gênero de Deus, normalmente visto como senhor, pai e homem. Guél escolhe chamar Deus de Deusa, característica também presente em seu primeiro trabalho. Para a autora, a divindade tem gênero e tal característica parece sustentar aquilo que Alice já repetia no outro álbum como um atributo divino: “A Woman”, uma mulher. Ela continua sua história, mudando e transformando os significados comuns do relato da criação. A desobediência, aquilo que na história do Gênesis se relata enquanto pecado, parece mudar também. Guél diz que, na verdade, a queda da humanidade tradicionalmente entendida como culpa da mulher, agora é atribuído a um mundo invadido pelo ego. O mundo perde o sentido quando o ego, o dinheiro e a vaidade viram a base das relações sociais. Essa situação fez com que o espaço que Deyse (metonímia para Deusa) havia criado se transformasse num espaço de conflito. Mas, em meio ao caos, ainda existiam aquelas de bom coração que entendiam o que era afeto e intimidade, bases essenciais que haviam sido destruídas.

O mito da criação na obra gueliana é a introdução para uma mensagem de restauração. Em sua história, Deyse separa uma mulher que carrega em si todos os corpos "transvestisgeneres negras, deslocados [...] pra entrar nessa arca”. Era necessário um dilúvio para que pudesse ser construída uma nova humanidade, pois aquela que existia já não servia, por não comportar nenhum corpo marginalizado. É importante perceber que o símbolo messiânico de Alice, aquele que trará a restauração do mundo, está representado no corpo de uma mulher trans e negra, considerado pela sociedade como corpo deslocado. Dessa mulher, ou, desses sujeitos oprimidos, simbolizados neste corpo transgênero, virá a salvação:

O mundo me quer inteira / E ainda me quer disposta / Me usa como teste, como aposta / Mas meu corpo é a própria prova / Que o mundo me quer ativa e morta / Mas agora é a minha vez / Minha plenitude 
/ Minha atitude, o meu jeito, os meus trejeitos / A minha neca, os meus dedos, a minha boca / Agora é a minha vez, a minha volta / A minha voz, o meu refúgio / O meu templo, agora é o meu tempo / Então comece o dilúvio ${ }^{34}$.

A poesia acima é parte da primeira faixa do EP Alice em frente ao espalho. A música que vem em seguida chama-se Dilúvio. Toda a introdução feita tanto pelo mito cosmogônico como pelo poema Reflexões, se conectará com diversos elementos da música Dilúvio e o restante da obra. A começar com a frase inicial: "Quero sentir afeto / Então chega mais perto / Faço chover no deserto se você precisar / Me encontrei no escuro, tô driblando o mundo / Caçando um canto seguro pra gente se plantar" (Alice GUÉL, 2019). Tanto a frase "quero sentir afeto" como "caçando um canto seguro pra gente se plantar" são elementos presentes no seu mito de criação. Nesta história mítica sobre a origem do mundo, afeto e intimidade constituem-se em características fundamentais das relações humanas que foram perdidas, mas que em Dilúvio, serão novamente plantadas em uma nova terra pós-diluviana, proporcionando um lugar seguro para o desejo do refrão: "Quero poder crescer, ramificar florescer / Crer e ser".

A poesia de Alice Guél é um tipo de prece de esperança. Uma oração pela restauração deste mundo, afim de que floresça o novo. E a água, a chuva, são os elementos utilizados como figura de linguagem, simbolizando um ato de limpeza desta sociedade suja, resultado da queda inicial, que precisa voltar aos propósitos de Deyse. Assim como na história bíblica, no dilúvio de Alice Guél, a água e a chuva representam início, nova aliança e salvação, sem deixar de lado a proeminência do corpo travesti: "Chuva de vida trava / Lava, invade, refaz, restaura / Rio de vida trava / Nutre, inunda, conduz, nos sara / Chuva de vida trava / Toma toda terra seca torna fértil toda alma / Rio de vida trava / Mata sede das sedentas que com fé me destrava".

A centralidade do corpo travesti é assumida como condição de santidade, e não mais de pecado. É uma condição para a salvação. Assim como o arco-íris na história bíblica é a marca do favor, misericórdia e a

34 Alice Guél, “Reflexões”. EP Alice em frente ao espalho (São Paulo, Trava Records, 2019). 
aliança de Deus com Noé e sua família, o corpo travesti em Dilúvio é a marca de um novo tempo, simbolizando a paz e o favor divino à criação:

Fascinada pelo nada / Esquecida pelo todo / Eu tô gritando é por socorro / Pra Deise me salvar / Sensível como uma pedra / Eu tô fumando minha erva / E construindo a nossa arca pro dilúvio começar / Me renova, tá ficando foda / Eu já nem vejo a hora / Do dilúvio começar e tudo recomeçar / Refaz e faz de novo / Só se salva quem crê na trava / Só se salva quem entra na arca / Só se salva quem tem a marca35.

A linguagem teopoética do rap de Alice Guél denuncia injustiças e violências. Assim como as palavras do profeta Amós eram palavras das quais "a terra não pode suportar" (Am 7.10), a obra gueliana possui dimensões diluvianas, palavras de denúncia que incomodam e evocam destruição e arrependimento dos poderosos, racistas e transfóbicos. Pois: "Quando eu falo que a gente tá sendo morta, a gente tá sendo morta mesmo [...] [Uma] mana que mora em casa apanhou 4 vezes em 2 meses. 4 vezes. E não foram tipo, apanhar pouco não. Tipo, apanhar de bater a cabeça dela no vidro do espelho do banheiro, de levar murro, de quebrar garrafa, levar murro na boca, sabe? De ficar com cicatriz" (Alice GUÉL, 2017).

O rap é "a letra que foi feita para ser escutada", é a criação de uma "harmonia no som das palavras" (Walter GARCIA, 2004, p. 170), é a intersecção entre uma visão crítica da sociedade e uma experiência estética, mística e erótica. A poética de Alice Guél está entrelaçada a uma experiência interior de dimensões universais, alcançando o desejo de continuidade intrínseco à existência descontínua dos corpos oprimidos. A partir de uma linguagem popular, erótica e religiosa, os versos de Alice Guél criam novas realidades e adquirem força crítica e teológica, do qual podemos extrair desses elementos sua teopoética. Essa experiência mística não é alienada ou conformada com a injustiça. É um convite para o protagonismo do corpo: "o discurso religioso, assim, é a expressão-protesto da criatura oprimida impossibilitada de se realizar dentro das condições dominantes. [...seus desejos] Realizam-se

35 Alice Guél, “Dilúvio”. EP Alice em frente ao espelho (São Paulo, Trava Bizness, 2019). 
nos símbolos religiosos, que se constituem num horizonte para a ação" (Rubem ALVES, 1999, p. 46).

Esse corpo oprimido de que fala Alice Guél, é um corpo herético, poético e protestante: "A potência herética é a potência do erótico que clama pela liberdade de voz do seu próprio corpo" (Danilo MENDES, 2019, p. 22). O corpo contém e expressa dimensões políticas, eróticas e espirituais. É a concretização de um feito de um letramento de reexistência (Ana Souza, 2011), que existe e resiste em meio às situações sociais adversas reivindicando não só lugar de fala, mas o de revelação sagrada, onde a Deusa encarna na realidade à nossa própria imagem e semelhança: Deus é travesti.

\section{CONSIDERAÇÕES FINAIS}

A obra de Alice Guél se apresenta como desafio tanto para o rap brasileiro como para a teologia cristã. De maneira inédita, ela pode ser encontrada não só entre as mais prestigiadas obras do rap nacional, mas entre as produções artísticas marginais que, aos poucos, conquista seu espaço nos estudos da religião. A experiência primária dessa poesia vem da oralidade e da escuta, se consagrando como literatura do cotidiano, escrita da vida, experiência erótica e religiosa de um corpo transgênero. Esta análise se faz pertinente não enquanto afirmação de alguma teologia existente, mas como provocação das estruturas da própria revelação cristã, abrindo um amplo debate no campo da teopoética. Guél faz da literatura oral urbana sua teologia, ou melhor, usa os textos sagrados para reescrever a própria experiência mística a partir das questões que o seu corpo apresenta. Portanto, a religião e o desenvolvimento teopoético de Alice Guél se constituem como base para qualquer tipo de interpretação que se pretenda fazer sobre a obra.

Tentamos refletir a literatura oral urbana como possibilidade de revisão e diálogo com a teologia cristã, abrindo espaço à pluralidade de identidades de gênero nos estudos teológicos. Analisamos como Alice Guél reivindica o corpo transexual como chave hermenêutica para uma experiência mística e erótica, problematizando também a imagem heteronormativa que se tem de Deus. A experiência que se faz da Deusa-travesti nos dois álbuns se relaciona diretamente ao corpo que sofre, 
que goza e que ora. Um corpo estético e político que se encarna como "Correnteza impetuosa contra o mundo machucado", que com "poder e glória cura o corpo alvejado"36.

\section{REFERÊNCIAS}

AGAMBEN, Giorgio. Profanações. São Paulo: Boitempo, 2007.

ALICE GUÉL. Alice no país que mais mata travestis, 2017. Disponível em: https://www. youtube.com/watch?v=T9KV8gLkihE\&t=9s. Acesso em: 14 mai. 2020.

ALICE GUÉL. Alice em frente ao espelho, 2019. Disponível em: https://www.youtube. com/watch?v=09NtDJYCbjo\&list=PLPdjKhiDQb8AoalbtYy7lc1Xljqpl2oJf. Acesso em: 18 mai. 2020.

ALTHAUS-REID, Marcella. Indecent Theology: Theological Perversions in Sex, Gender and Politics. London: Routledge, 2001.

ALVES, Rubem. O suspiro dos oprimidos. São Paulo: Paulus, 1999.

ALVES, Rubem. Variações sobre a vida e a morte. Ou o feitiço erótico-herético da teologia. São Paulo: Edições Loyola, 2009.

ARAUJO, Ayni Estevão. Entre manas e manos: Uma etnografia com o movimento de mulheres do Hip-Hop e a Casa do Hip Hop Sanca. Dissertação (Mestrado em Antropologia Social) - Programa de Pós Graduação em Antropologia Social, Universidade Federal de São Carlos. São Carlos/SP, 2016.

BARCELLOS, José Carlos. Literatura e teologia: Perspectivas teórico-metodológicas no pensamento católico contemporâneo. In: Numem - Revista de estudos e pesquisa da religião, v. 3, n. 2, Juiz de Fora, 2000, pp. 9-30.

BATAILLE, Georges. O erotismo. Belo Horizonte: Autêntica, 2017.

BROWN, Mano. In: TRIP TV. Mano Brown e Francisco Bosco discutem lugar de fala e apropriação cultural, 2018. Disponível em: https://www.youtube.com/ watch?v=LjUiDoQEb9o. Acesso em: 15 mai. 2020.

CANTARELA, Antônio Geraldo. A produção acadêmica em Teopoética no Brasil: pesquisadores e modelos de leitura. Revista Teoliterária, v. 8, v. 15, 2018, pp. 193-221.

CLARO, Paula Cabrera; PEREIRA, Ariane Carla. Sexismo nas letras de rap: A sedimentação do machismo pela música. $6^{\circ}$ Colóquio Mulher e Sociedade, Universidade Estadual de Ponta Grossa, Ponta Grossa, 23 e 24 de abril de 2019.

CUNHA, Thaís. Brasil lidera ranking mundial de assassinato de transexuais. Correio Braziliense, s/d. Disponível em: http://especiais.correiobraziliense.com.br/brasil-lidera-ranking-mundial-de-assassinatos-de-transexuais. Acesso em: 18 mai. 2020.

36 Alice Guél, “Dilúvio”, EP Alice em frente ao espelho (São Paulo, Trava Bizness, 2019). 
CRIOLO. Sempre em tempo. Revista Trip, 16 mai. 2016. Entrevista concedida a Camila Eiroa. Disponível em: https://revistatrip.uol.com.br/trip/criolo-fala-sobre-relancamento-de-ainda-ha-tempo-dez-anos-depois. Acesso em: 15 mai. 2020.

DALASAM, Rico. Rico Dalasam: “O rap é homofóbico, mas também é grande”. El País, 13 ago. 2016. Entrevista concedida a Camila Moraes. Disponível em: https://brasil.elpais. com/brasil/2016/08/11/cultura/1470928039_323923.html. Acesso em: 24 ago. 2020.

D’ANDREA, Tiarajú Pablo. A formação dos sujeitos periféricos: Cultura e Política na periferia de São Paulo. São Paulo. Tese (Doutorado em Sociologia). Universidade de São Paulo, São Paulo, 2013.

FERREIRA, Felipe Trevisan; CRISTÓVÃO, Vera Lúcia Lopes. “Mc's de verdade não desejam sociedades sem diversidades": o rap LGBT nas aulas de língua portuguesa. In: Entretextos, Londrina, v. 19, n. 1, 2019, pp. 109-142.

GARCIA, Walter. Ouvindo Racionais Mc's. Teresa - Revista de Literatura Brasileira, São Paulo, v. 4, n. 5, 2004, pp. 166-180.

GUÉL, Alice. 2017. Caneca LAB (YouTube). Disponível em: https://www.youtube.com/ watch?v=53njCW7lkZw\&list=LLZ_PP-uZa1fCyF-XA_MiE3Q\&index=15\&t=0s. Acesso em: 13 mai. 2020.

GUÉL, Alice; DELLACROIX, Mc. 2017. Jaque Ramirez (YouTube). Disponível em: https:// www.youtube.com/watch?v=UBKsdluTKpQ. Acesso em: 15 mai. 2020.

GUÉL, Alice. 2017a. Alice Guél (YouTube). Disponível em: https://www.youtube.com/ watch?v=zjllyVU_NHE. Acesso em: 13 mai. 2020.

GUÉL, Alice. Alice Guél no país que mais mata travestis. Hendrix War, 28 fev. 2018. Entrevista concedida a Fábio Nunes. Disponível em: https://hendrixwar.wordpress. com/2018/02/28/alice-guel-no-pais-que-mais-mata-travestis. Acesso em: 13 mai. 2020.

GUÉL, Alice. 2018a. Profusão Cultural (YouTube). Disponível em: https://www.youtube. com/watch?v=Ucs25_tCtOo\&t=331s. Acesso em: 13 mai. 2020.

GUÉL, Alice. 2019. Batalha Dominação (YouTube). Disponível em: https://www.youtube. com/watch?v=GMgZkAnqzxw. Acesso em: 19 mai. 2020.

GUÉL, Alice. 2020. Festival MARSHA! (YouTube). Disponível em: https://www.youtube. com/watch?v=IwgUGWNItkY. Acesso em: 19 mai. 2020.

JESUS, Jaqueline Gomes (Org.). Transfeminismo: teorias e práticas. Rio de Janeiro: Metanoia, 2014.

MENDES, Danilo. De uma ética herética: a análise de um conceito político-religioso. Numem - Revista de Estudos e Pesquisa da Religião, Juiz de Fora, v. 22, n. 2, 2019, pp. 21-32. NOS TEMPOS DA SÃO BENTO. Break And Style Crew (YouTube). Disponível em: https:// www.youtube.com/watch?v=z8FtlypGeVs. Acesso em: 19 mai. 2020.

OLIVEIRA, Roberto Camargos. Rap e política: Percepções da vida social brasileira. São Paulo: Boitempo, 2015. 
QUEEN, Tiely. Hip-hop fora do armário: quando a cultura hip-hop derruba barreiras da sociedade retrograda. Revista da ABNP, v. 10, Ed. Especial - Caderno Temático: Letramentos de Reexistência, 2018, pp. 461-471.

RODRIGUES, Maria Natália Matias. Jovens mulheres rappers: reflexões sobre gênero e geração no Movimento Hip Hop. Recife. Dissertação (Mestrado em Psicologia). Universidade Federal de Pernambuco, Recife, 2013.

SALGADO, Marcus Rogério. Entre ritmo e poesia: rap e literatura oral urbana. Scripta, Belo Horizonte, v. 19, n. 37, 2015, pp. 151-163.

SANTOS, Sandra Mara Pereiros. Relações de Gênero no cenário do rap brasileiro: muIheres negras e brancas. Colóquio Internacional Culturas Jovens Afro-Brasil América: Encontros e Desencontros Anais do Primeiro Colóquio Internacional Culturas Jovens Afro-Brasil América: Encontros e Desencontros. São Paulo, abr. 2012.

SOUZA, Ana Lúcia Silva. Letramentos de Reexistência. Poesia, Grafite, Música, Dança: Hip-Hop. São Paulo, Parábola, 2011.

SOUZA, Angela Maria. Repensando as relações de gênero através das práticas musicais de jovens: O movimento Hip-hop. Seminário internacional Fazendo Gênero 9 - Diásporas, diversidades e deslocamentos. Florianópolis, 23 a 26 ago. 2010.

Submetido em: 25-8-2020

Aceito em: 7-10-2020 